\title{
Decapod Crustaceans of the Barents Sea and adjacent waters: species composition and peculiarities of distribution
}

\author{
Аесятиногие ракообразные Баренщева моря и прилежкащей \\ акватории: видовой состав и особенности распределения
}

\author{
O.L. Zimina ${ }^{1}$, P.A. Lyubin ${ }^{2}$, L.L. Jørgensen ${ }^{3}$, \\ D.V. Zakharov ${ }^{2}$, O.S. Lyubina ${ }^{1}$

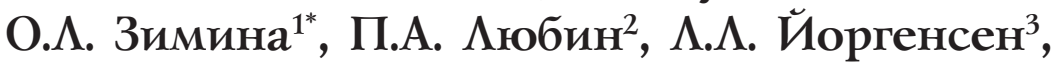

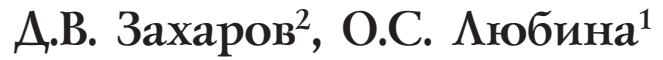

\footnotetext{
${ }^{1}$ Murmansk Marine Biological Institute KSC RAS (MMBI), Vladimirskaya str. 17, Murmansk, 183010, Russia.

${ }^{2}$ Knipovich Polar Research Institute of Marine Fisheries and Oceanography (PINRO), Academic Knipovich str. 6, Murmansk, 183038, Russia.

${ }^{3}$ Institute of Marine Research (IMR), Sykehusveien 23, Tromsø, 9019, Norway.

*Correspondening author; E-mail: zimina@mmbi.info,o.1.zimina@gmail.com

${ }^{1}$ Мурманский морской биологический институт КНЦ РАН (ММБИ), ул. Владимирская, д.17, Мурманск, 183010, Россия.

${ }^{2}$ Полярный научно-исследовательский институт морского рыбного хозяйства и океанографии им. Н.М. Книповича (ПИНРО), ул. Академика Книповича, д. 6, Мурманск, 183038, Россия.

*Автор, которому должна быть адресована корреспонденция; E-mail: zimina@mmbi.info, o.l.zimina@gmail.com
}

KEY WORDS. Arctic, distribution, species composition, ecological groups, waters masses.

КЛЮЧЕВЫЕ СЛОВА. Арктика, распределение, видовой состав, экологические группы, водные массы.

ABSTRACT. Species composition and pattern of distribution of decapod crustaceans in the Barents Sea and adjacent waters have been described using the material of the PINRO-IMR trawling survey of the 2011 year. Twenty five decapod species were identified. According to their global distribution $40 \%$ of them are boreal species, and 46\% — boreal-arctic species. Essential information on environmental conditions of occurrence and maps of distribution in the studied area are presented for each species. Four ecological groups of the Decapoda have been revealed by means of Canonical Correspondence Analysis: "warm water", "cold water", "deep water" and "widespread" species. Borderline of distribution of the "warm" and "cold water" decapod species is located north-eastward from respective biogeographical borderlines drawn in earlier periods, i.e. decades ago [Golikov, 1968; Antipova et al., 1989; Galkin, 1992; Bryazgin, 1997] and reflects the ongoing period of warming in the Arctic.

РЕЗЮМЕ. По материалам траловой съемки ИМР-ПИНРО 2011 г. описан видовой состав десятиногих ракообразных Баренцева моря и прилежащей акватории Гренландского и Норвежского морей. Выявлено 25 видов декапод. 40\% видов являются бореальными, 44\% - бореально-арктическими. Приведены краткие сведения об условиях среды и карты распространения видов по исследованной акватории. Методом канонического анализа соответствия (ССА) выделено 4 экологических группы десятиногих ракообразных, обусловленные в первую очередь температурой и глубиной обитания: «тепловодные», «холодноводные», «глубоководные», «широко распространённые». Проведена граница распространения «тепловодных» и «холодноводных» видов, которая расположена к северовостоку от аналогичных границ, выявленных несколько десятилетий назад [Golikov, 1968; Антипова и др., 1989; Галкин, 1992; Bryazgin, 1997], что отражает текущий период потепления в Арктике.

\section{Introduction}

Decapoda are a widespread group in the Arctic seas. They hold important positions in the benthic and nectobenthic communities, including food resource for fish and other vertebrate animals and consumers of smaller benthic species. This group is not very diverse, while some species have commercial importance.

Fauna of the decapod crustaceans of the Eurasian seas of the Arctic Ocean, including the Barents Sea is relatively well studied. Several publications [i.e. Yashnov, 1948; Sokolov, 2002, 2003, 2006, 2009; Petryashov, 2009; Vasilenko, 2009] present data on taxonomy, biology, ecology and biogeographical status of Decapoda species in the seas of the Arcic Ocean. However, information on spatial distribution of the decapod species in the Barents Sea in relation to oceanographic 
conditions is rather scarce. A characteristic feature of Decapoda is the presence of free-swimming pelagic larvae, which makes possible broad dispersal of species by means of marine currents. Early stages of development are especially sensitive to environmental factors, in particular temperature [Thorson, 1950]. Many species of Decapoda are stenoecios and are associated with water masses having particular thermo-haline characteristics. That is why some Decapoda species are used as indicators of water masses and temperature conditions in the detection of environmental, in particular climatic changes [Blacker, 1965; Dyer, 1984; Berge et al., 2009].

Annual joint Russian-Norwegian ecosystem surveys in the Barents Sea and adjacent waters of the Greenland and Norwegian Seas, which are conducted by the Polar Research Institute of Marine Fisheries and Oceanography (PINRO, Murmansk) and Institute of Marine Research (IMR, Bergen), provide unique possibility to obtain actual data on composition and spatial distribution of the benthic species in this area [Jørgensen et al., 2015]. Bottom trawl "Campelen 1800" used in ecosystem surveys is a specialized gear for shrimp fishing. Owing to the method of collecting decapod crustaceans are a regular component of trawl by-catch and their species richness reaches $17 \%$ of total benthic species in hauls [Lyubin et al., 2010].

The aim of this paper is to describe species composition and pattern of spatial distribution of Decapoda in the Barents Sea and adjacent waters based on the materials obtained in the trawl surveys of 2011 year.

\section{Study area}

Barents Sea has complex bottom topography and oceanographical regime. Depth between 100 and $300 \mathrm{~m}$ are typical for the most of the area. Several banks with depth 50-200 $\mathrm{m}$ and basins and trenches with the maximum depth of about $500 \mathrm{~m}$ are located at the northern and western boundary of the marine basin [Dobrovolsky, Zalogin, 1982; Matishov, 1986]. Four main water masses are present in the Barents Sea: the warm Atlantic water, the cold Arctic water, the cold Barents Sea water and the warm Coastal waters [Ozhigin, Ivshin, 1999]. Oceanographical regime of the Barents Sea is greatly influenced by the Norwegian Atlantic current, which brings warm $\left(1-8^{\circ} \mathrm{C}\right)$ waters from the Atlantic Ocean. It flows to the south-western part of the sea as the North Cape current and diverges then into several brunches and reaches the eastern parts of the sea. Part of the Norwegian Current waters move to the north along the continental slope (known as the Spitsbergen current), round the Spitsbergen archipelago and moves eastward, partly penetrating into the Barents Sea from the north through the deep Franz-Victoria and St. Anna Troughs. Colder Arctic Water $\left(<0^{\circ} \mathrm{C}\right)$ dominates in the northern Barents Sea. In the south-western part of Barents Sea near-bottom water temperature is always above-zero [Matishov et al., 2009; Boitsov et al., 2012].
Since the late 1980 s and until present time warm climatic period continues in the Barents Sea which is associated with increasing advection of warm Atlantic water [Matishov et al., 2010].

\section{Material and methods}

This paper is based on materials collected during the joint PINRO-IMR ecosystem survey of the Barents Sea and adjacent waters in the year 2011. Material was collected by specialists onboard Norwegian research vessels "Helmer Hansen", "Christina E", "Johan Hjort" and Russian research vessel "Vilnius", using the same bottom trawl "Campelen-1800" [Walsh, McCallum, 1997] on all vessels. The trawl is made of the caprone net with the mesh size $125 \mathrm{~mm}$ in the front part and 22 $\mathrm{mm}$ in the cod end. Mouth opening of the trawl is approximately $15 \mathrm{~m}$ (horizontal) to $4 \mathrm{~m}$ (vertical). Standard trawling time was $15 \mathrm{~min}$ after the trawl hit the bottom with average speed of about 3 knots. In case of changing the trawling time, catch data were standardized to $15 \mathrm{~min}$ trawl time. The following specialists collected material, identified species and processed data on board: O.L. Zimina aboard RVs Helmer Hansen and Christina E, O.S. Lyubina aboard RV Johan Hjort, D.V. Zakharov aboard RV Vilnius.

Decapod crustaceans from each haul were identified to the maximum possible taxonomic level, biomass (with accuracy to $0.1 \mathrm{~g}$ ) and number of individuals were recorded. Material from 363 trawling stations was analyzed (Fig. 1). The taxonomic arrangement in the text follows the recent advances in decapods systematic and classification changes. In particular several caridean genera earlier assigned to Hyppolitidae Bate, 1888 are now considered within Bythocarididae Cristoffersen, 1988 and Thoridae Kingsley, 1879 [De Grave et al., 2014].

Canonical Correspondence Analysis (CCA) [Legendre, Legendre, 1998] based on species presence/absence data was used for analyzing species distribution in dependence to environmental factors (temperature, depth, salinity) and for revealing ecological groups of Decapoda. Statistical calculations and plotting were made using statistical package "PAST" [Hammer et al., 2001].

\section{Results and discussion}

\section{Species composition}

According to the latest reviews [List of species..., 2001; Sokolov, 2003] 40 species of Decapoda occur in the Barents Sea. In the materials of 201125 decapod species from 18 genera and 10 families were identified. Essential information about spatial distribution and habitats for each species according our data is presented below. Zoogeographical characteristics and global distribution pattern of species are provided according to several sources [Komai, 1999; Sirenko, 2001; Sokolov, 2002, 2003, 2009; Petryashov, 2009; Vasilenko, 2009; www.marinespecies.org]. 


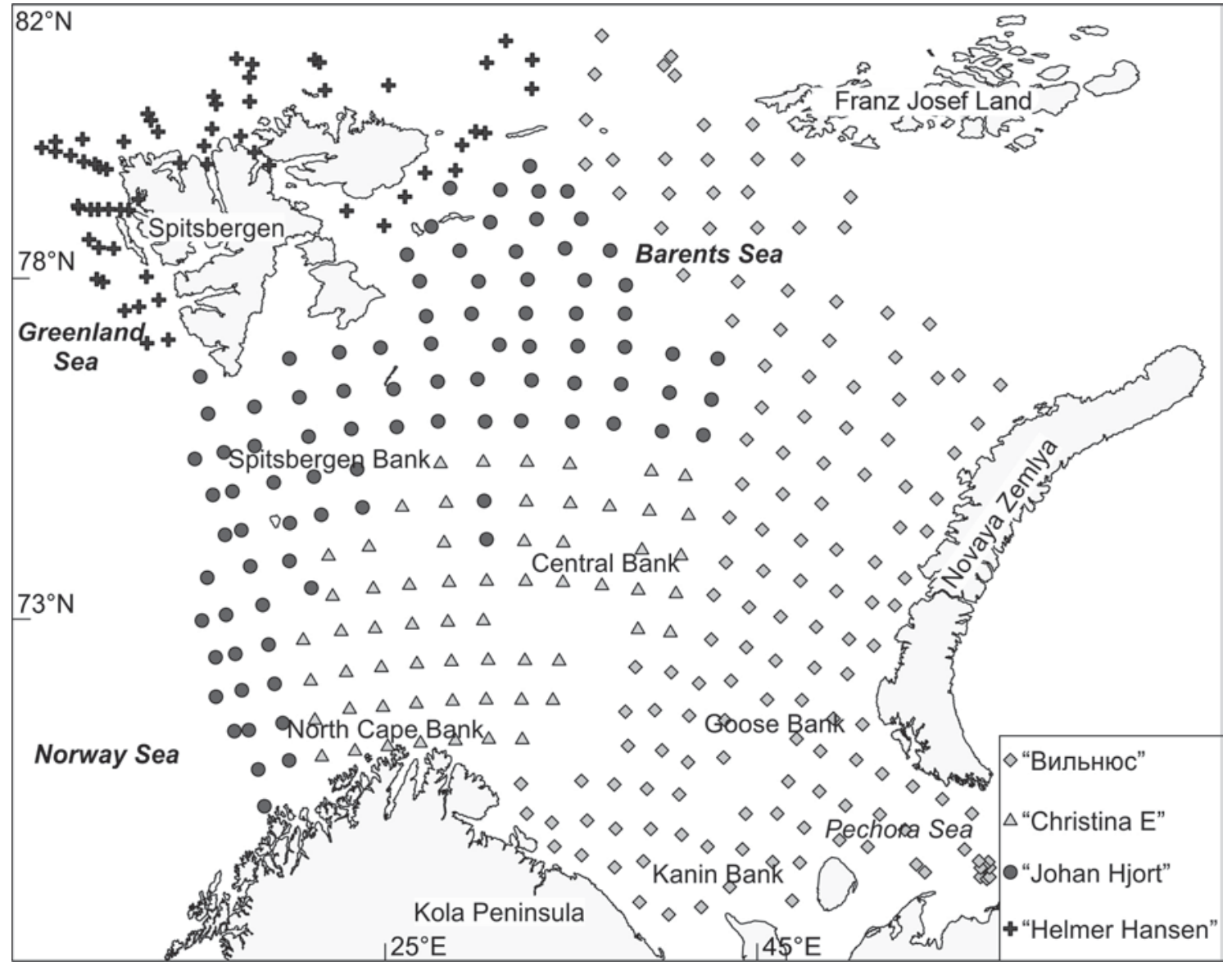

Fig. 1. Map of sampling stations in the Barents Sea and adjacent waters in 2011.

Рис. 1. Карта-схема расположения траловых станций в Баренцевом море и сопредельной акватории в 2011 г.

Order Decapoda

Suborder Dendrobranchiata Bate, 1888

Family Sergestidae Dana, 1852

Eusergestes arcticus (Krøyer, 1855)

MATERIAL. 358 ind., 3 stations, depth 400-600 m, temperature $-0,7 \ldots+1.3^{\circ} \mathrm{C}$, salinity $34,7-35,1 \%$. Abundance $3-196$ individuals per trawling, biomass $4-164 \mathrm{~g}$ per trawling.

DISTRIBUTION. Panoceanic bathyal-abyssal species occurring westward of Greenland, in the Northern Atlantic, including the western Barents Sea, Mediterranean, and the Indo-Pacific region. In our survey the species is recorded westward of the Spitsbergen Archipelago and near the Franz Josef Land Archipelago (Fig. 2).

Suborder Pleocyemata Burkenroad, 1963

Infraorder Caridea Dana, 1852

Family Acanthephyridae Bate, 1888

Hymenodora glacialis (Buchholz, 1874)

MATERIAL. 33 ind., 3 stations, depth 600-900 m, temperature $-0,7 \ldots+2^{\circ} \mathrm{C}$, salinity $34,90-35,03 \%$. Abundance $5-10$ individuals per trawling, biomass $5-14 \mathrm{~g}$ per trawling.
DISTRIBUTION. Panoceanic bathyal species occurring in the Northern Atlantic and Pacific, Polar Basin, Kara, Laptev, and East-Siberian Seas. In our material it was recorded northward of the Spitsbergen Archipelago (Fig. 2).

Family Bythocarididae Cristoffersen, 1988

Bythocaris biruli Kobjakova, 1964

MATERIAL. 1 ind., 1 station, depth $580 \mathrm{~m}$, temperature $0,46^{\circ} \mathrm{C}$, salinity $34,77-35,1 \%$. Abundance 1 individuals per trawling, biomass $2.5 \mathrm{~g}$ per trawling.

DISTRIBUTION. Arctic bathyal species. Greenland, Norway, Barents, Kara, Laptev, East-Siberian seas. In our material it was recorded only once in the Franz Josef - Victoria Trough (Fig. 2).

Bythocaris payeri (Heller, 1875)

MATERIAL. 31 ind., 4 stations, depth 600-900 m, temperature $-0,7 \ldots+2^{\circ} \mathrm{C}$, salinity $34,90-35,03 \%$. Abundance $1-16$ individuals per trawling, biomass $1-17 \mathrm{~g}$ per trawling.

DISTRIBUTION. Widespread boreal Atlantic-Arctic species. North Atlantic and Arctic oceans, Green- 


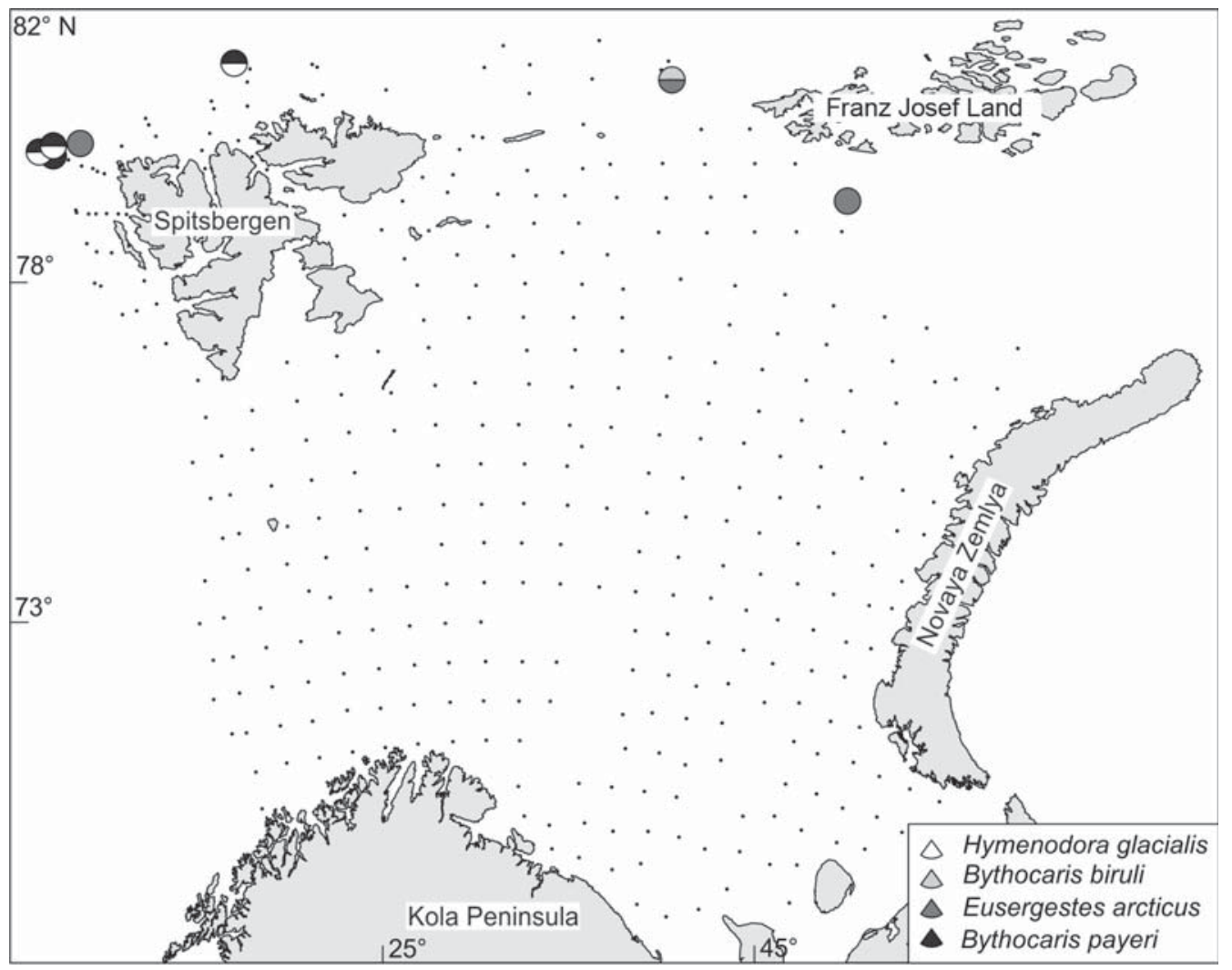

Fig. 2. Distribution of Eusergestes arcticus, Hymenodora glacialis, Bythocaris biruli and B. payeri in the study area.

Рис. 2. Распространение на исследованной акватории Eusergestes arcticus, Hymenodora glacialis, Bythocaris biruli и B. payeri.

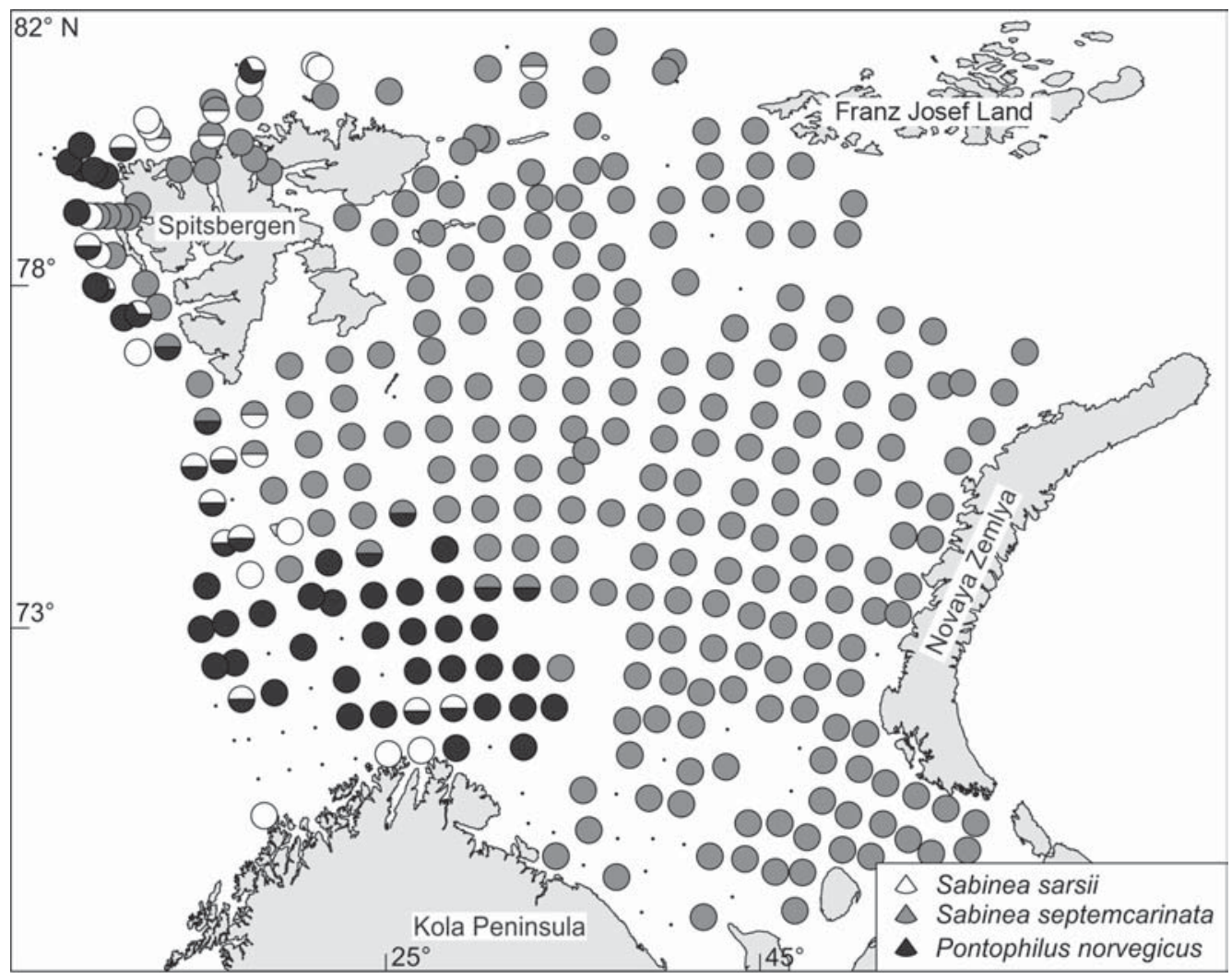

Fig. 3. Distribution of Pontophilus norvegicus, Sabinea sarsi and S. septemcarinata in the study area.

Рис. 3. Распространение на исследованной акватории Pontophilus norvegicus, Sabinea sarsi и S. septemcarinata. 


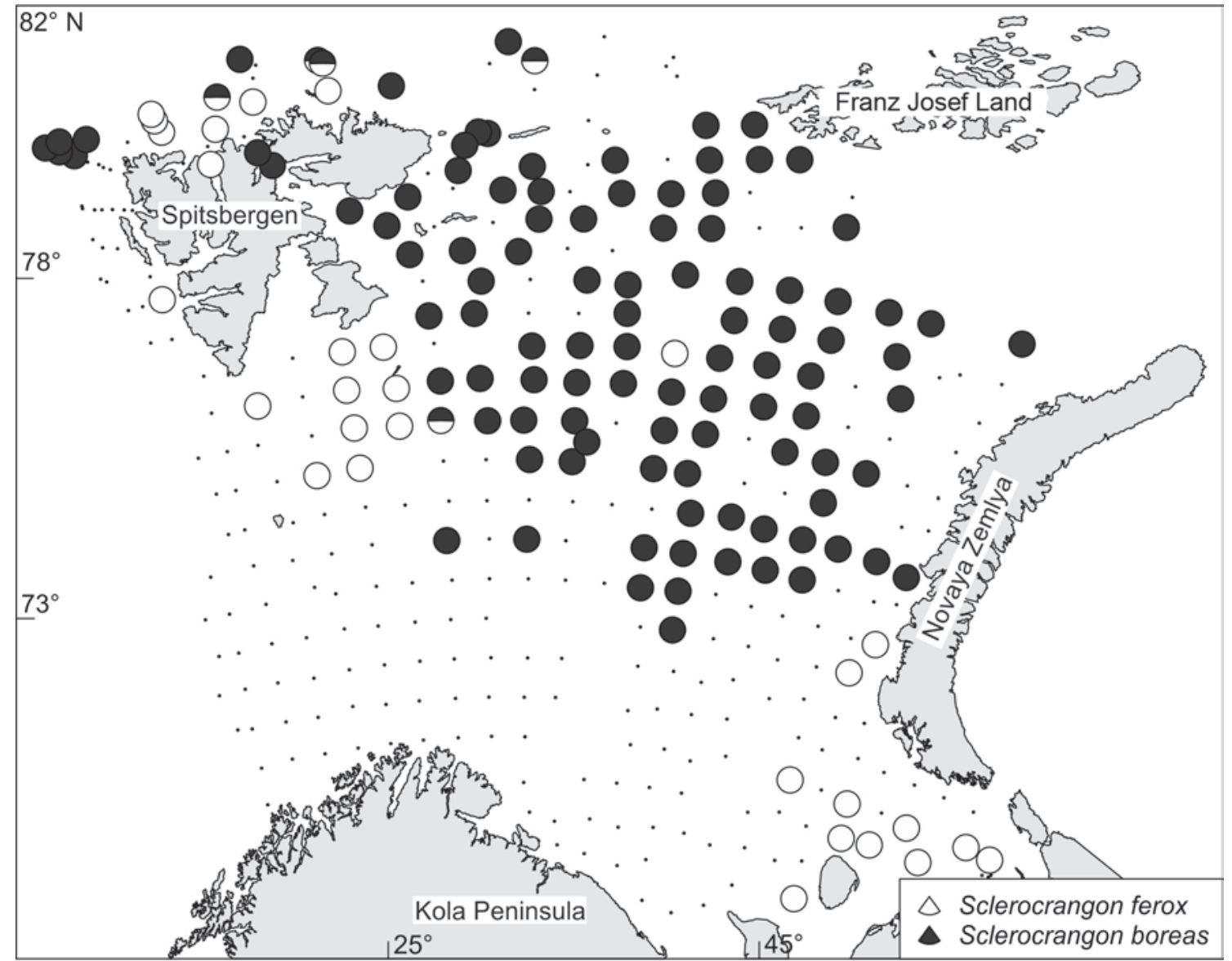

Fig. 4. Distribution of Sclerocrangon boreas and S. ferox in the study area.

Рис. 4. Распространение на исследованной акватории Sclerocrangon boreas и S. ferox.

land, Norway, Barents, Kara, Laptev, and East-Siberian Seas. In our material it was recorded northward of the Spitsbergen Archipelago (Fig. 2).

Family Crangonidae Haworth, 1825

Pontophilus norvegicus (M. Sars, 1861)

MATERIAL. 518 ind., 58 stations, depth 100-600 m, temperature $0 \ldots+5.5^{\circ} \mathrm{C}$, salinity $34.8-35.2 \%$. Abundance $1-45$ individuals per trawling, biomass $0.1-80 \mathrm{~g}$ per trawling.

DISTRIBUTION. Widespread Atlantic boreal species. Northern Atlantic, near Greenland, Iceland, Spitsbergen archipelago, along the eastern coast of North America and the northern coast of Europe, in the western Barents Sea. In our material it was recorded in the western part of the studied area (Fig. 3).

Sabinea sarsii Smith, 1879

MATERIAL. 392 ind., 33 stations, depth 80-600 m, temperature $+1.4 \ldots+7^{\circ} \mathrm{C}$, salinity $34.0-35.2 \%$. Abundance $1-70$ individuals per trawling, biomass $1-140 \mathrm{~g}$ per trawling.

DISTRIBUTION. Widespread Atlantic boreal species. Davis Strait, near Iceland, along the eastern coast of North America and the northern coast of Europe, in the Barents and White seas. In our survey it recorded in the western part of studied area and northward of the Spitsbergen archipelago (Fig. 3).

\section{Sabinea septemcarinata (Sabine, 1824)}

MATERIAL. 392 ind., 33 stations, depth 80-600 m, temperature $+1.4 \ldots+7{ }^{\circ} \mathrm{C}$, salinity $34.0-35.2 \%$. Abundance $1-70$ individuals per trawling, biomass $1-140 \mathrm{~g}$ per trawling.

DISTRIBUTION. High boreal - Arctic circumpolar species. Northern Atlantic, near Greenland, Iceland, along the eastern coast of North America and in all Arctic seas of Russia. In our survey it has been recorded in the major part of studied area, except southwestern area (Fig. 3). Greatest abundance was found in the northern Pechora Sea and along the coast of the Novaya Zemlya archipelago.

\section{Sclerocrangon boreas (Phipps, 1774)}

MATERIAL. 1062 ind., 34 stations, depth 20-270 m, temperature $-0.7 \ldots+4{ }^{\circ} \mathrm{C}$, salinity $33.4-35.1 \%$. Abundance $1-500$ individuals per trawling, biomass 2-3800 g per trawling.

DISTRIBUTION. High boreal - Arctic circumpolar species. Near Greenland, Iceland, Spitsbergen archipelago, along the eastern coast of North America 


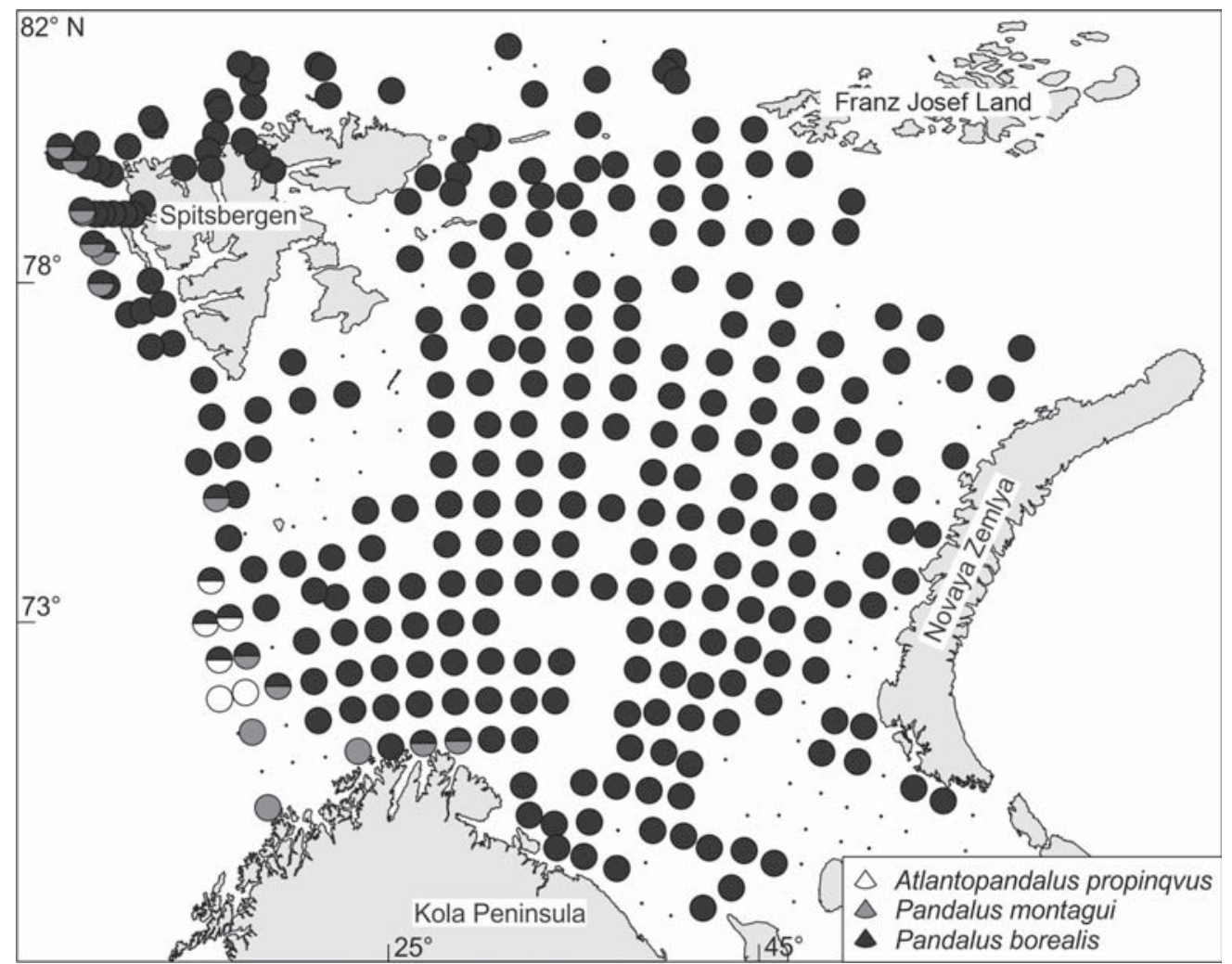

Fig. 5. Distribution of Atlantopandalus propinqvus, Pandalus montagui and P. borealis in the study area.

Рис. 5. Распространение на исследованной акватории Atlantopandalus propinqvus, Pandalus montagui и P. borealis.

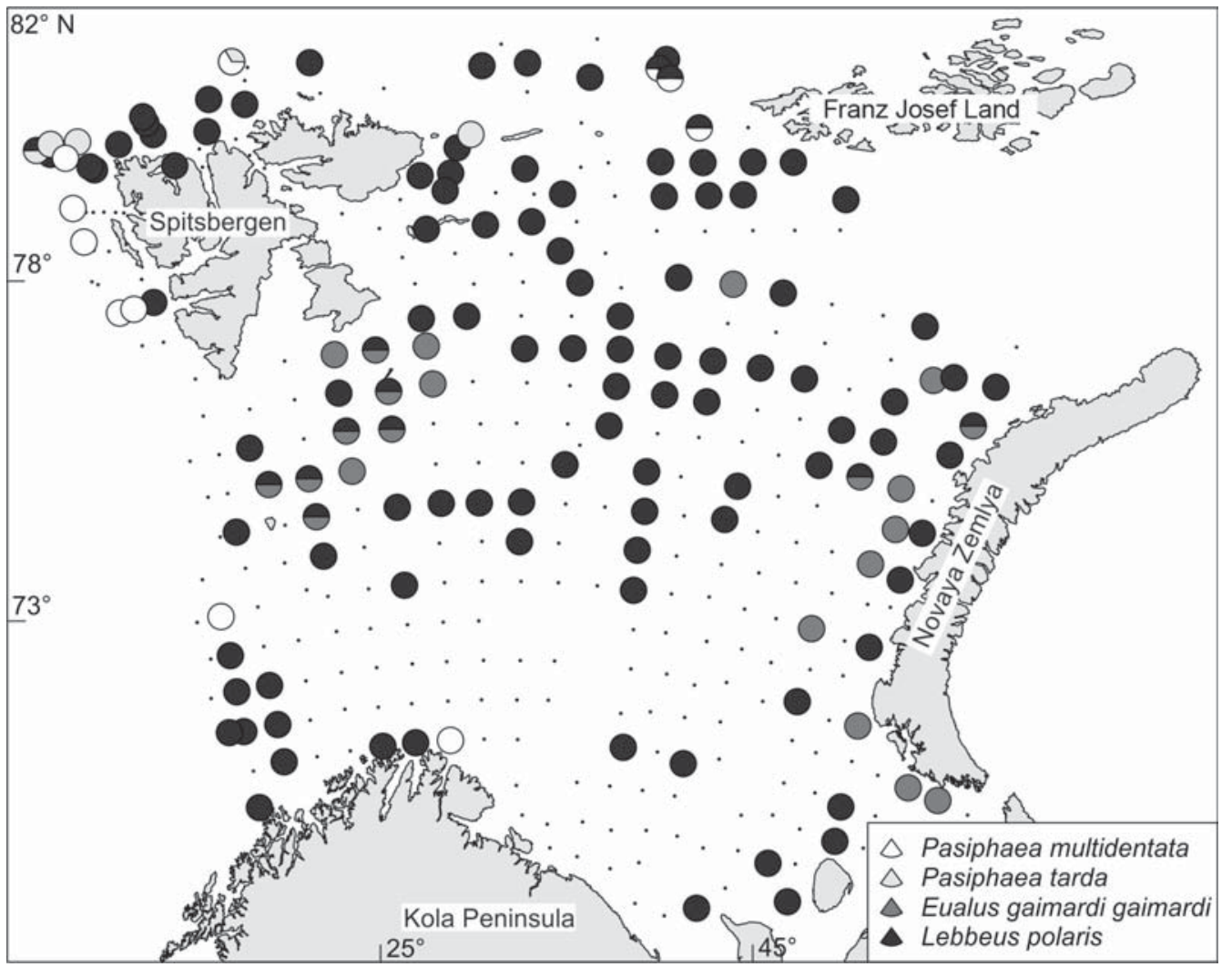

Fig. 6. Distribution of Pasiphaea. multidentata, P. tarda, Eualus gaimardii gaimardii and Lebbeus polari in the study area.

Рис. 6. Распространение на исследованной акватории Pasiphaea. multidentata, P. tarda, Eualus gaimardii gaimardii и Lebbeus polaris. 


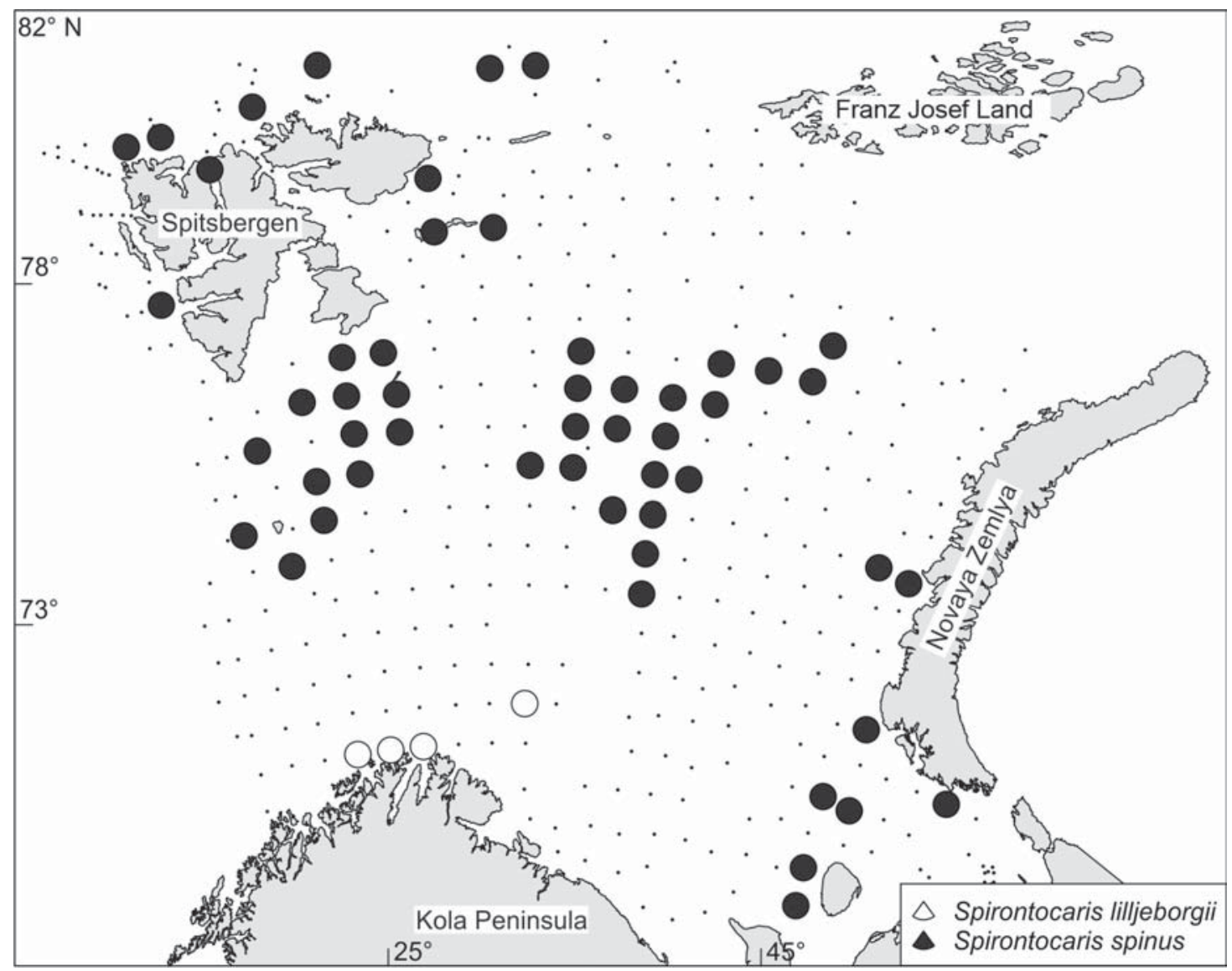

Fig. 7. Distribution of Spirontocaris lilljeborgii è S. spinus in the study area.

Рис. 7. Распространение на исследованной акватории S. lilljeborgii и S. spinus.

and in all Arctic and Far-Eastern seas of Russia. In our survey the species was found in the south-eastern part of the Barents Sea (Pechora Sea), in the Spitsbergen bank area, where highest abundance has been recorded, and northward of the Spitsbergen archipelago (Fig. 4).

\section{Sclerocrangon ferox (Sars G.O., 1877)}

MATERIAL. 4766 ind., 106 stations, depth 60-900 m, temperature $-1.2 \ldots+3^{\circ} \mathrm{C}$, salinity $34.3-35.1 \%$. Abundance $1-1000$ individuals per trawling, biomass $1.5-9000 \mathrm{~g}$ per trawling.

DISTRIBUTION. High boreal - Arctic circumpolar species. Near Greenland, Iceland, Spitsbergen archipelago, along the eastern coast of North America and in all Arctic seas of Russia. In our material it was recorded mainly in the northern Barents Sea and northward of the Spitsbergen archipelago (Fig. 4). Highest abundance was recorded in the north-eastern of Barents Sea and near the Franz Joseph Land archipelago.

Family Pandalidae Haworth, 1825

Atlantopandalus propinqvus (Sars G.O., 1870)

MATERIAL. 211 ind., 6 stations, depth 300-500 m, temperature $+2 \ldots+6^{\circ} \mathrm{C}$, salinity $35.0-35.2 \%$. Abundance $2-75$ individuals per trawling, biomass 4-170 g per trawling.
DISTRIBUTION. Atlantic subtropical-boreal species. Northern Atlantic, near Greenland, Iceland, Norway, British Isles. We recorded this species only in the western part of the studied area (Fig. 5).

\section{Pandalus borealis borealis Krøyer, 1838}

MATERIAL. 503565 ind., 277 stations, depth $70-900 \mathrm{~m}$, temperature $-1,3 \ldots+5^{\circ} \mathrm{C}$, salinity $34.2-35.2 \%$. Abundance $1-20000$ individuals per trawling, biomass $0,6-102900 \mathrm{~g}$ per trawling.

DISTRIBUTION. Widespread boreal Atlantic Arctic species. North-western Atlantic, Barents, White, Kara, Laptev seas. Commercial species. In our material it was recorded in the major part of the studied area (Fig. 5). The species was most abundant in the central part of the Barents Sea and around Spitsbergen archipelago.

\section{Pandalus montagui Leach, 1814}

MATERIAL. 220 ind., 15 stations, depth 200-600 m, temperature $0 \ldots+7^{\circ} \mathrm{C}$, salinity $34.9-35.2 \%$. Abundance $1-100$ individuals per trawling, biomass $0.7-240 \mathrm{~g}$ per trawling.

DISTRIBUTION. Widespread boreal AtlanticArctic species. Northern Atlantic, near Greenland, Iceland, along the northern coast of Europe, off British Isles, in the Barents and White seas. In our materi- 


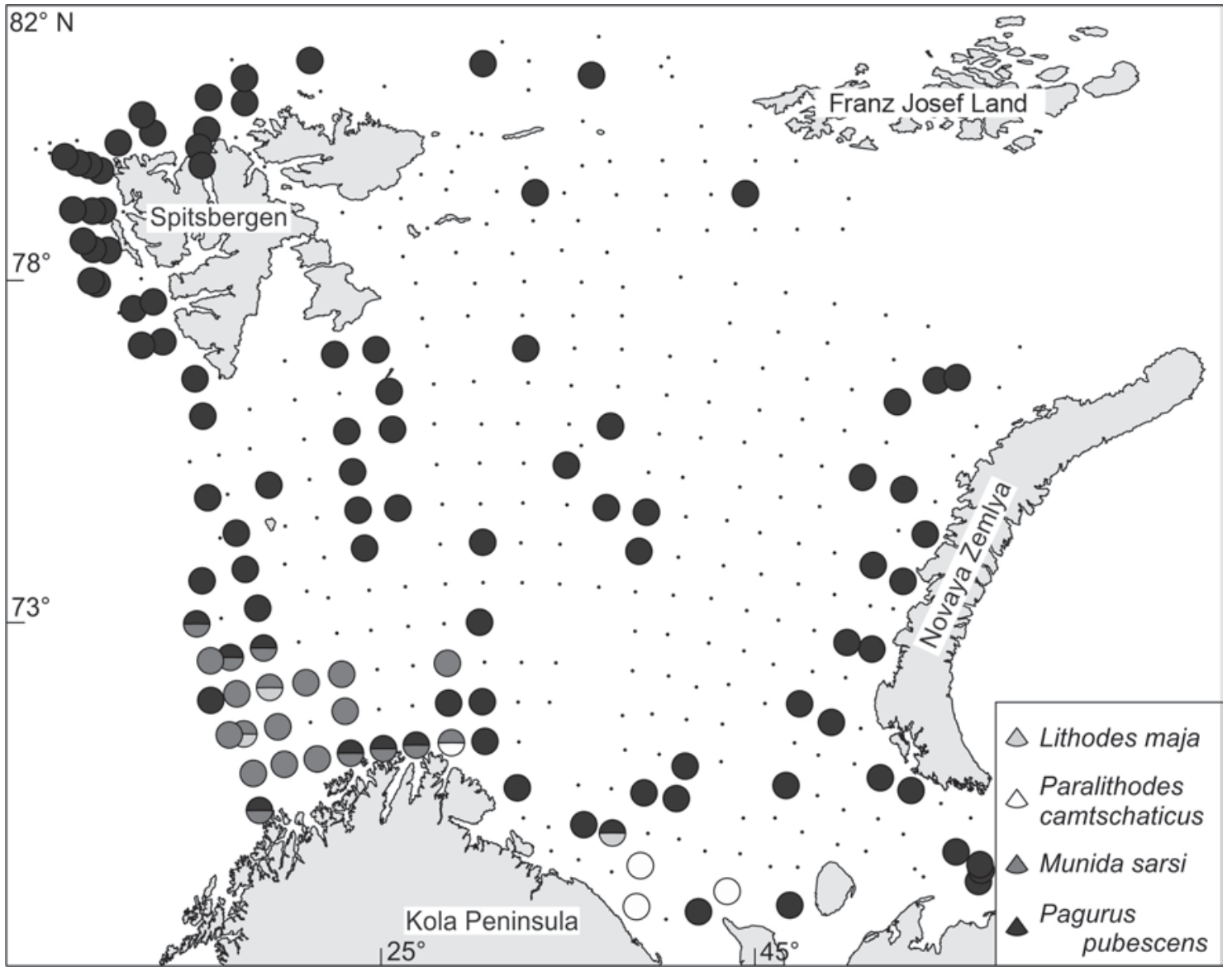

Fig. 8. Distribution of Lithodes maja, Paralithodes camchaticus, Munida sarsi and Pagurus pubescens in the study area.

Рис. 8. Распространение на исследованной акватории Lithodes maja, Paralithodes camchaticus, Munida sarsi и Pagurus pubescens.

al it was recorded in the western part of the studied area (Fig. 5).

Family Pasiphaeidae Dana, 1852

Pasiphaea multidentata Esmark, 1866

MATERIAL. 420 ind., 11 stations, depth 200-900 m, temperature $-0,4 \ldots+4{ }^{\circ} \mathrm{C}$, salinity $34,77-35,07 \%$. Abundance $1-200$ individuals per trawling, biomass $0.5-400 \mathrm{~g}$ per trawling.

DISTRIBUTION. Atlantic subtropical-boreal. Pelagic species occuring in the Eastern and Western Atlantic, near Greenland, off Norway's coast, in the North Sea, Mediterranean Basin and the western part of the Barents Sea. In our data it was recorded in the western and northern parts of the studied area (Fig. 6). The highest abundance of the species was detected near the western coast of Western Spitsbergen Island.

\section{Pasiphaea tarda Krøyer, 1845}

MATERIAL. 91 ind., 5 stations, depth 300-900 m, temperature $-0,7 \ldots+2^{\circ} \mathrm{C}$, salinity $34,82-35,03 \%$. Abundance $1-50$ individuals per trawling, biomass $0.5-250 \mathrm{~g}$ per trawling.

DISTRIBUTION. Panoceanic bathypelagic species occurring in the Northern Atlantic, high-latitude Arc- tic, the western part of the Barents Sea. In our material it was recorded northward of the Spitsbergen Archipelago (Fig. 6).

Family Thoridae Kingsley, 1879 1837)

Eualus gaimardii gaimardii (H. Milne Edwards,

MATERIAL. 3418 ind., 22 stations, depth 45-300 m, temperature $-1 \ldots+4^{\circ} \mathrm{C}$, salinity $34.0-35.0 \%$. Abundance $1-640$ individuals per trawling, biomass $1-1000 \mathrm{~g}$ per trawling.

DISTRIBUTION. High boreal - Arctic species. Northern Atlantic, Barents, White, Kara, Laptev seas. In our data it was recorded mainly near the Novaya Zemlya archipelago, where densest accumulation was observed, and in the Spitsbergen Bank area (Fig. 6).

Lebbeus polaris (Sabine, 1824)

MATERIAL. 2534 ind., 112 stations, depth 45-900 m, temperature $-1.3 \ldots+7^{\circ} \mathrm{C}$, salinity $33.6-35.2 \%$. Abundance $1-300$ individuals per trawling, biomass $0.5-500 \mathrm{~g}$ per trawling.

DISTRIBUTION. Circumpolar high boreal - Arctic species. Northern Atlantic, all seas of the Arctic Ocean and Northern Pacific. In our survey it was re- 


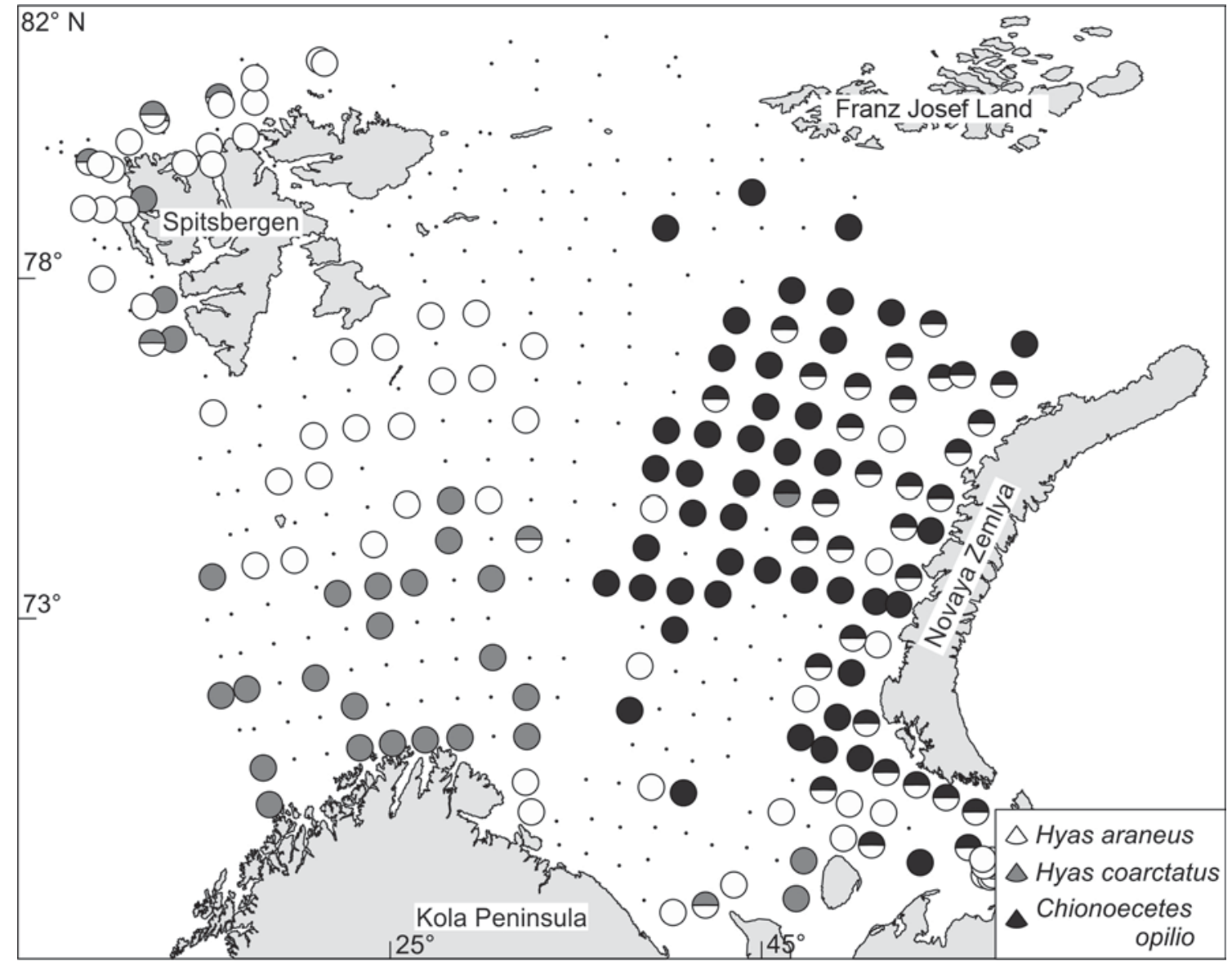

Fig. 9. Distribution of Hyas araneus, H. coarctatus and Chionoecetes opilio in the study area.

Рис. 9. Распространение на исследованной акватории Hyas araneus, H. coarctatus и Chionoecetes opilio.

corded in the major part of the studied area, but mainly in north (Fig. 6). Greatest abundance was observed near the Novaya Zemlya, Franz Joseph Land and the Spitsbergen archipelagoes.

\section{Spirontocaris liljeborgii (Danielssen, 1859)}

MATERIAL. 23 ind., 4 stations, depth $150-300 \mathrm{~m}$, temperature $+3 \ldots+5^{\circ} \mathrm{C}$, salinity $34,97-35,03 \%$. Abundance $1-12$ individuals per trawling, biomass $1-8 \mathrm{~g}$ per trawling.

DISTRIBUTION. High boreal Atlantic - Arctic species. Northern Atlantic, Greenland, Norwegian and the western Barents seas. In the present survey the species was recorded in the south-western part of studied area off Northern Norway coast (Fig. 7).

\section{Spirontocaris spinus (Sowerby, 1805)}

MATERIAL. 410 ind., 52 stations, depth 45-300 m, temperature $-1,3 \ldots+4^{\circ} \mathrm{C}$, salinity $33,5-35,0 \%$. Abundance $1-50$ individuals per trawling, biomass $1-115 \mathrm{~g}$ per trawling.

DISTRIBUTION. High boreal - Arctic species. Northern Atlantic, Barents, White, Kara, Laptev seas, and the eastern Chukchi Sea. In our material it was recorded mainly in the central and north-western parts of studied area and near the Novaya Zemlya archipelago (Fig. 7). It was most abundant in the area of the Central Bank and the Spitsbergen Bank.

Infraorder Anomura MacLeay, 1838

Family Lithodidae Samouelle, 1809

Lithodes maja (Linnaeus, 1758)

MATERIAL. 5 ind., 3 stations, depth $140-330 \mathrm{~m}$, temperature $+2.4 \ldots+6.5^{\circ} \mathrm{C}$, salinity $34.8-35.2 \%$. Abundance $1-3$ individuals per trawling, biomass $23-45$ g per trawling.

DISTRIBUTION. Widespread boreal Atlantic species. Along the eastern coast of North America, near British Isles, Northern Norway, in the south-western Barents Sea. In our survey it occurred in the southwestern part of studied area (Fig. 8).

\section{Paralithodes camtschaticus (Tilesius, 1815)}

MATERIAL. 39 ind., 4 stations, depth $65-140 \mathrm{~m}$, temperature $+2.3 \ldots+4^{\circ} \mathrm{C}$, salinity $34.25-34.98 \%$. Abundance $1-34$ individuals per trawling, biomass $700-13800 \mathrm{~g}$ per trawling.

DISTRIBUTION. Widespread boreal Pacific species. Northern Pacific, Okhotsk, Japan, Bering, Chuk- 


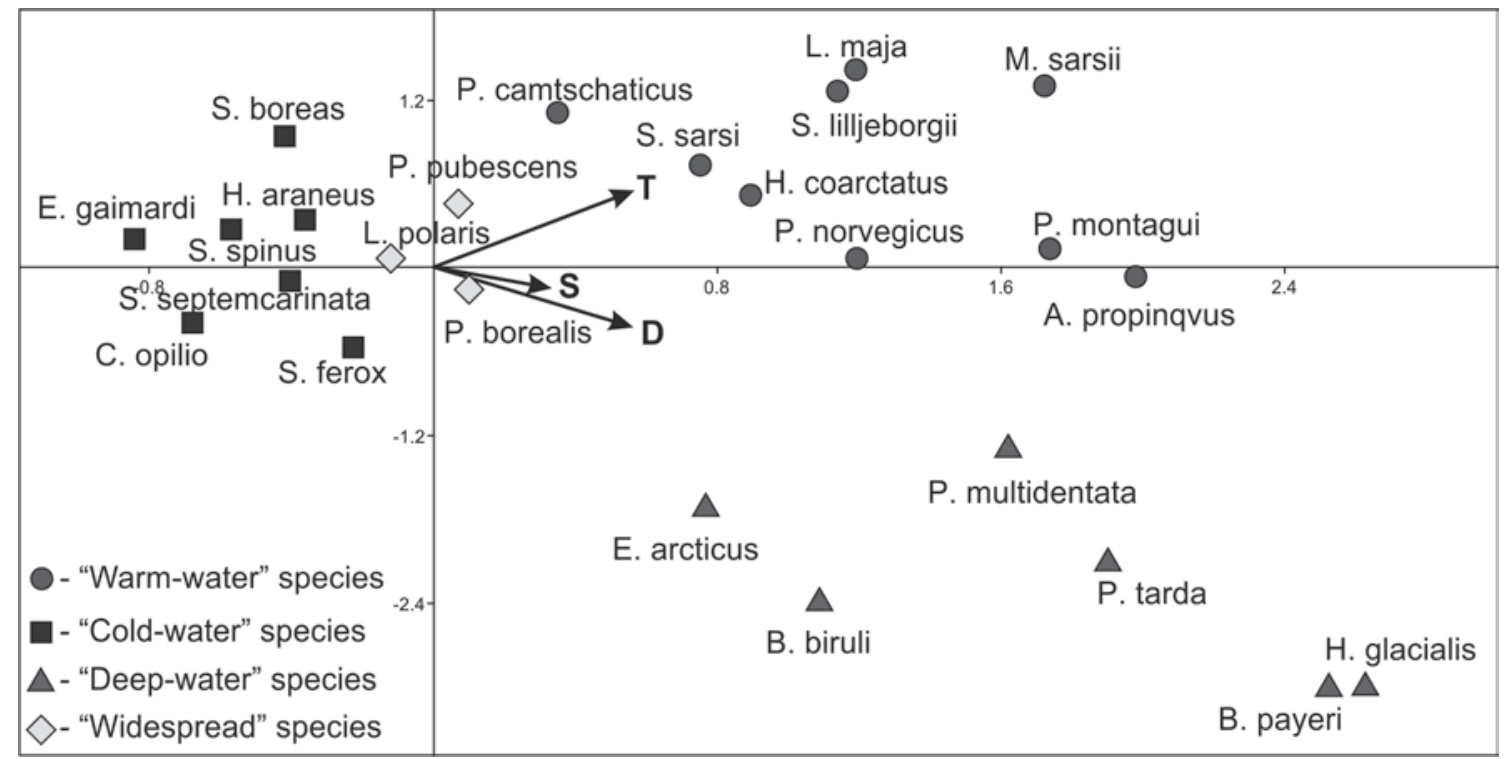

Fig. 10. CCA ordination of Decapoda species in dependence of environmental variables ( $\mathrm{T}$ - near-bottom temperature, $\mathrm{S}$ - salinity, D - depth).

Рис. 10. Ординация методом CCA видов Decapoda в зависимости от факторов среды (T - придонная температура, $\mathrm{S}-$ соленость, D - глубина).

chi Seas. Introduced in the southern Barents Sea. Commercial species. In our data it was recorded in the southern part of studied area, near North Cape and in the Kanin bank (Fig. 8).

Family Munididae Ahyong, Baba, Macpherson, Poore, 2010

\section{Munida sarsi Huus, 1935}

MATERIAL. 748 ind., 21 stations, depth 150-500 m, temperature $+3.5 \ldots+7^{\circ} \mathrm{C}$, salinity $34.9-35.2 \%$. Abundance $1-247$ individuals per trawling, biomass $4-1600 \mathrm{~g}$ per trawling.

DISTRIBUTION. Atlantic boreal species, occurring near Greenland, Iceland, along the coast of Northern Europe from British Isles to northern Norway, in the south-western Barents Sea. In our survey it recorded only in the south-western part of studied area (Fig. 8).

Family Paguridae Latreille, 1802

Pagurus pubescens Krøyer, 1838

MATERIAL. 440 ind., 93 stations, depth 20-600 m, temperature $-1.3 \ldots+7^{\circ} \mathrm{C}$, salinity $33.6-35.1 \%$. Abundance $1-120$ individuals per trawling, biomass $0.1-670 \mathrm{~g}$ per trawling.

DISTRIBUTION. Widespread boreal Atlantic-Arctic species. Greenland, Iceland, along the eastern coast of North America and the coast of Northern Europe, in the Barents, White, Kara Seas. In our material it recorded mainly in the western and eastern parts of studied area (Fig. 8). The species was most abundant in the Goose Bank area and northward of the Spitsbergen archipelago.
Infraorder Brachyura MacLeay, 1838

Family Oregoniidae Garth, 1958

Hyas araneus (Linnaeus, 1758)

MATERIAL. 1144 ind., 97 stations, depth $15-500 \mathrm{~m}$, temperature $-1.3 \ldots+5.5^{\circ} \mathrm{C}$, salinity $33.6-35.1 \%$. Abundance $1-500$ individuals per trawling, biomass $0.1-26600 \mathrm{~g}$ per trawling.

DISTRIBUTION. Widespread boreal - Arctic species. Iceland, Spitsbergen archipelago, along the eastern coast of North America and the northern coast of Europe, in the Barents, White, Kara Seas. In our material it was recorded mainly in the western and eastern parts of studied area (Fig. 9). Most abundant in the Goose Bank area.

\section{Hyas coarctatus Leach, 1816}

MATERIAL. 94 ind., 34 stations, depth 50-500 m, temperature $-0.3 \ldots+7^{\circ} \mathrm{C}$, salinity $33.5-35.2 \%$. Abundance $1-30$ individuals per trawling, biomass $0.1-2600 \mathrm{~g}$ per trawling.

DISTRIBUTION. Widespread Atlantic boreal species. Greenland, Spitsbergen archipelago, along the eastern coast of North America and Northern Europe coast, Barents, White. The species formerly listed as $H$. coarctatus for the East-Siberian, and Chukchi, Bering and the Okhotsk seas is now regarded as Hyas alutaceus Brandt, 1851. In our survey it was recorded mainly in the western part of studied area (Fig. 9). The species was most abundant near the western coast of the Spitsbergen archipelago.

\section{Chionoecetes opilio (O. Fabricius, 1788)}

MATERIAL. 6199 ind., 75 stations, depth 40-360 m, temperature $-1 \ldots+3^{\circ} \mathrm{C}$, salinity $33.4-35.0 \%$. Abundance $1-1900$ individuals per trawling, biomass $1-19600 \mathrm{~g}$ per trawling. 
DISTRIBUTION. Pacific-western Atlantic boreal Arctic. Northern Pacific (Okhotsk, Japan, Bering Seas), north-western Atlantic (south-east of Greenland, eastern coast of Canada), Arctic Ocean (Beaufort, Chukchi, Laptev Seas). In 1996 it was found in the Barents Sea [Kuzmin et al., 1998], recently recorded in the Kara Sea [Zimina, 2014]. Commercial species. In the present survey it was found mainly in the eastern part of studied area (Fig. 9). The greatest abundance was recorded near North Island of the Novaya Zemly a archipelago and in the Goose Bank area.

\section{Distribution patterns in relation to the envi- ronmental factors}

Fauna of the decapod crustaceans in the Barents Sea is characterized by a large fraction of boreal species $(40 \%)$. Their distribution in the study area is limited by the zone of Atlantic waters influence: southwestern part of the Barents Sea, western and northern deep-water regions. Boreal-arctic species compose $44 \%$ of the total number of species and are distributed over major part of the studied area.

Species distribution in relation to the environmental factors (temperature, depth and salinity) was analyzed using the CCA and four ecological groups of Decapoda were identified (Fig. 10).

Relatively warm-water species living at moderate depth are "indicators" of the Atlantic waters in the study area (M. sarsi, L. maja, S. lilljeborgii, P. camtschaticus, $S$. sarsi, $H$. coarctatus, $P$. norvegicus, $P$. montagui, $A$. propinqvus). They occur in the western and south-western parts of study area, their distribution is limited by the Atlantic water distribution with elevated temperature and salinity. In the south-western Barents Sea they spread up to the $74^{\circ} \mathrm{N}$ and $34^{\circ} \mathrm{E}$, round the Spitsbergen archipelago, some species penetrate to the central and eastern Barents Sea with the warm Atlantic flow.

Deep-water species of the transformed Atlantic water mass are associated with waters with high salinity and lower temperature (B. biruli, B. payeri, $P$. multidentata, P. tarda, E. arcticus, and H. glacialis). They are restricted to the deepest northern and western parts of study area near the continental slope.

Cold-water species are associated with low temperature Arctic and Barents Sea water masses (S. ferox, $S$. septemcarinata, E. gaimardi, C. opilio, S. boreas, $S$. spinus, and $H$. araneus). They do not occur in the relatively warm Atlantic waters in the south-western part of study area. Around the Spitsbergen archipelago the cold-water species are mainly restricted to the coastal zone.

Widespread species occur all over study area, both in the Atlantic and Arctic water masses (P. borealis, $L$. polaris and P. pubescens).

Species of first three groups are distributed in the study area in correspondence to the distribution of water masses and near-bottom temperatures in 2011 (Fig. 11, a). We can draw the approximate borderline of modern distribution of "cold-water" and "warmwater" decapod species in the Barents Sea and adjacent waters (Fig. 11, b). Its location generally corresponds to the borderlines, drawn on the basis of the distribution of other benthic taxonomic groups according to the recent data [Zakharov, Lyubin, 2012; Jørgensen et al., 2015]. These contemporary frontiers are located north-eastward from respective biogeographical borderlines drawn in earlier periods, i.e. decades ago [Golikov, 1968; Antipova et al., 1989; Galkin, 1992; Bryazgin, 1997] and reflect the ongoing period of warming in the Arctic.

Moderate species diversity, relative simplicity of identification, frequent occurrence in the trawl hauls make decapods a convenient group for the ecosystem monitoring in the Barents Sea and other areas. Distribution of particular species groups in certain regions reflect hydrological conditions and can be used in the study of climatic changes' influence on the marine ecosystem. Presented distribution maps of decapod spe-

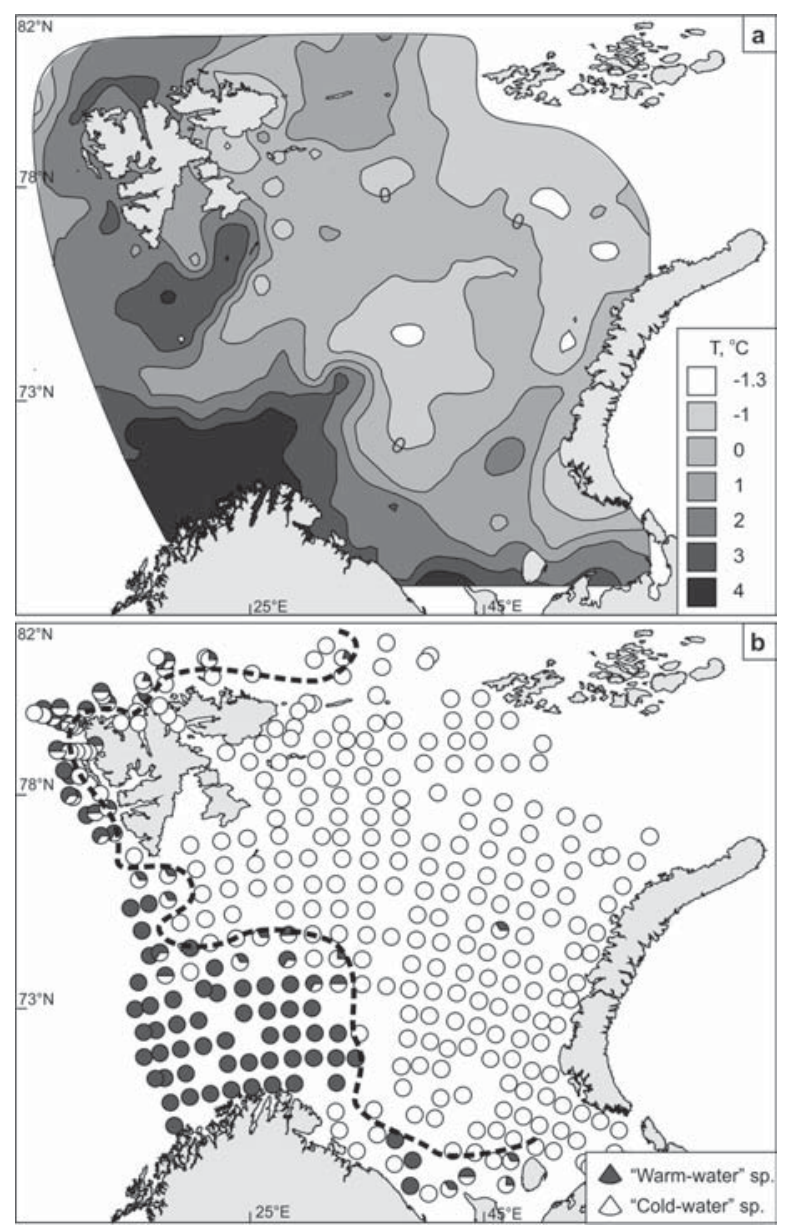

Fig. 11. Near-bottom temperature in the study area in 2011 (a) and distribution of "warm-water" and "cold-water" Decapoda species (b).

Рис. 11. Распределение придонной температуры в районе исследований в 2011 г. (а) и распространение «тепловодных» и «холодноводных» видов декапод (b). 
cies and ecological groups can be used as a baseline for the state of decapod fauna in the warm climatic period, which has begun in the late 1980s and continues until now.

ACKNOWLEDGMENTS. Authors thank the crew and scientific groups on board the Russian and Norvegian research vessels for help and support in field work. We thank Dr. Vassily A. Spiridonov for critical reviewing of the manuscript, constructive comments and corrections.

\section{References}

Antipova T.V., Denisenko N.V., Semenov V.N. 1989. [Distribution of bottom fauna and problems of biogeographic division of northern seas] // Zhizn i sreda Polyarnykh morey. Leningrad: Nauka. P.146-157 [in Russian].

Berge J., Renaud P.E., Eiane K., Gulliksen B., Cottier F.R., Varpe O., Brattegard T. 2009. Changes in the decapod fauna of an Arctic fjord during the last 100 years (1908-2007) // Polar Biology. Vol.32. No.7. P.953-961.

Blacker R.W. 1965. Recent changes in the benthos of West Spitsbergen Fishing grounds // Special publications. International comission for the Northweast Atlantic Fisheries. Vol.6. P.791794.

Boitsov V.D., Karsakov A.L., Trofimov A.G. 2012. Atlantic water temperature and climate in the Barents Sea, 2000-2009 // ICES Journal of Marine Science. Vol.69. No.5. P.833-840.

Bryazgin V.F. 1997. Diversity, distribution and ecology of benthic amphipods (Amphipoda, Gammaridea) in the Barents Sea sublittoral // Polish Polar Recearch. Vol.18. No.2. P.89-106.

De Grave S., Li C.P., Tsang L.M., Chu K.H., Chan T.-Y. 2014. Unweaving hippolytoid systematics (Crustacea, Decapoda, Hippolytidae): resurrection of several families // Zoologica Scripta. Vol.43. No.5. P.496-507.

Dobrovolsky A.D., Zalogin B.S. 1982. [Seas of USSR]. Moscow: MSU. 192 p. [in Russian].

Dyer M.F., Cranmer G.J., Fry P.D., Fry W.G. 1984. The distribution of the benthic hydrographic indicator species in Swalbard waters // Journal of the Marine Biological Association of the United Kingdom. Vol.64. No.3. P.667-677.

Galkin Yu.I. 1992. [Climate and distribution of the Arctic Buccinidae] // Problemy kaynozoyskoy paleoecologii i paleogeographii morey Severnogo Ledovitogo Oceana. Moscow: Nauka. P.125-131 [in Russian].

Golikov A.N. 1968. Distribution and variability of long-lived benthic animals as indicators of currents and hydrological conditions // Sarsia. Vol.34. P.199-208.

Hammer Ø., Harper D.A.T., Ryan P.D. 2001. Past: Paleontological Statistics Software Package for Education and Data Analysis // Palaeontologia Electronica. Vol.4. No.1. P.1-9.

Jørgensen L.L., Lyubin P.A., Skjoldal H.R., Ingvaldsen R.B., Anisimova N.A., Manushin I.E. 2015. Distribution of benthic megafauna in the Barents Sea: baseline for an ecosystem approach to management // ICES Journal of Marine Science. Vol.72. No.2. P.595-613.

Komai T. 1999. A revision of the genus Pandalus (Crustacea: Decapoda: Caridea: Pandalidae) // Journal of Natural History. Vol.33. P.1265-1372.

Kuzmin S.A., Akhtarin S.M., Menis D.T. 1998. [The first finding of snow crab Chionoecetes opilio (Decapoda, Majidae) in the Barents Sea] // Zoologicheskiy zhurnal. Vol.77. No.4. P.489491 [in Russian].

Legendre P., Legendre L. 1998. Numerical Ecology. 2nd English ed. Elsevier Publ. 853 pp.

List of species of free-living invertebrates of Eurasian Arctic seas and adjacent deep waters. 2001. // Explorations of the fauna of the seas. Vol.51(59). Saint Petersburg: Zoological Institute of Russian Accademy of Sciences. 131 pp.
Lubin P.A., Anisimova N.A., Jørgensen L.L., Manushin I.E., Prochorova T.A., Zakharov D.V., Zhuravleva N.E., Golykov A.V., Morov A.R. 2010. [Megabenthos of the Barents Sea] // Kompleksnye issledovaniya prirody Spitsbergena. Priroda shelfa i archipelago Evropeyskoy Arktiki: Materialy mezhdunarodnoy nauchnoy konferencii. M.: GEOS. No.10. P.192-200 [in Russian]

Matishov G.G. 1986. [Bottom geomorphology in the sea ecosystems] // Zhizn i usloviya ee suschestvovania v bentali Barentseva morya. Apatity: KBAS USSR. P.5-26 [in Russian].

Matishov G.G., Matishov D.G., Moiseev D.V. 2009. Inflow of Atlantic-origin waters to the Barents Sea along glacial troughs // Oceanologia. Vol.51. No.3. P.321-340.

Matishov G.G., Dzhenuk S.L., Moiseev D.V., Zhichkin A.P. 2010. [Climatic changes in the marine ecosystems of the European Arctic] // Problemy Arktiki i Antarktiki. Vol.86. No.3. P.7-21 [in Russian].

Ozhigin V.K., Ivshin V.A.1999. [Water masses of the Barents Sea]. Murmansk: PINRO Press. 48 pp. [in Russian].

Petryashov V.V. 2009. [Supertribe Anomura (Order Decapoda, Suborder Reptantia)] // Illyustrirovannyye opredeliteli svobodnozhivushchikh bespozvonochnykh Yevraziyskikh morey i prilezhashchikh glubokovodnykh chastey Arktiki. Vol.1. Rotifera, Pycnogonida, Cirripedia, Phyllocarida, Euphasiacea, Anomura, Brachiura, Mysidacea, Natantia, Hyperiidea, Caprellidea. Moscow: KMK Scientific Press Ltd. P.101-111 [in Russian].

Sokolov V.I. 2002. [Decapod crustaceans (Crustacea Decapoda) of the Eurasian seas of Polar Basin]. Avtoreferat dissertatsii na soiskaniye stepeni Kandidata Biologicheskikh Nauk. Moscow: P.P. Shirshov Institute of Oceanology of RAS. 24 pp. [in Russian].

Sokolov V.I. 2003. [Decapod Crustaceans of the Barents Sea] // Trudy VNIRO. Vol.142. P.25-76 [in Russian].

Sokolov V.I. 2006. [Distribution of the hermit crabs Pagurus pubescens and P. bernhardus (Anomura, Paguridae) in the Barents Sea and White Sea Gorlo Strait] // Zoologicheskiy Zhurnal. Vol.85. No.10. P.1176-1186 [in Russian].

Sokolov V.I. 2009. [Suborder Natantia (Order Decapoda)] // Illyustrirovannyye opredeliteli svobodnozhivushchikh bespozvonochnykh Yevraziyskikh morey i prilezhashchikh glubokovodnykh chastey Arktiki. Vol.1. Rotifera, Pycnogonida, Cirripedia, Phyllocarida, Euphasiacea, Anomura, Brachiura, Mysidacea, Natantia, Hyperiidea, Caprellidea. Moscow; Saint-Petersburg: KMK Scientific Press Ltd. P.72-101 [in Russian].

Thorson G. 1950. Reproductive and larval ecology of marine bottom invertebrates // Biological Reviews. Vol. 25. No.1. P.1-45.

Vasilenko S.V. 2009. [Infraorder Brachyura (Order Decapoda)] // Illyustrirovannyye opredeliteli svobodnozhivushchikh bespozvonochnykh Yevraziyskikh morey i prilezhashchikh glubokovodnykh chastey Arktiki. Vol.1. Rotifera, Pycnogonida, Cirripedia, Phyllocarida, Euphasiacea, Anomura, Brachiura, Mysidacea, Natantia, Hyperiidea, Caprellidea. Moscow; Saint-Petersburg: KMK Scientific Press Ltd. P.111-120 [in Russian].

Walsh S.J., McCallum B.R. 1997. Performance of the Campelen1800 Shrimp Trawl during the 1995 Northwest Atlantic Fisheries // NAFO Science Council Studies. Vol.29. P.105-116.

WORMS World Register of Marine Species www.marinespecies.org

Yashnov V.A. 1948. [Order Decapoda] // Opredelitel fauny i flory severnykh morey SSSR. M.: Sovetskaya Nauka. P.328-344 [in Russian].

Zakharov D.V., Lyubin P.A. 2012. [Fauna, ecology and distribution of Buccinidae (Mollusca, Gastropoda) in the Barents Sea and adjacent waters] // Vestnik MGTU. Vol.15. No.4. P.749_ 757 [in Russian].

Zimina O.L. 2014. Finding the snow crab Chionoecetes opilio (O. Fabricius, 1788) (Decapoda: Majidae) in the Kara Sea // Russian Journal of Marine Biology. Vol.40. No.6. P.490-492.

Responsible editor V.A. Spiridonov 